Ethiopian Journal of Environmental Studies \& Management 7(4): 353 - 360, 2014

ISSN:1998-0507

doi: http://dx.doi.org/10.4314/ejesm.v7i4.2

Submitted: March 05, 2014

Accepted: June 12, 2014

\title{
ANALYSIS OF THE DUST GENERATED FROM POINT SOURCE IN RELATION TO THE DISTANCE FROM THE POINT OF GENERATION IN GBOSE QUARRY, OMU-ARAN, NIGERIA
}

*SALIU, M. A., LAWAL, A. I. AND ATIGRO, V. U.

Department of Mining Engineering, The Federal University of Technology, Akure, Nigeria

\begin{abstract}
The study analyzed the impacts of dust generated from the crushing plant (point source) to its immediate environment in Gbose Quarry. The objectives of the research were achieved through sample collection from the study area and quantitative method. The collected samples were labelled $\mathrm{SS}_{1}, \mathrm{SS}_{2}, \mathrm{SS}_{3}, \mathrm{SS}_{4}, \mathrm{SS}_{5}, \mathrm{SS}_{6}$ and $\mathrm{S}_{\mathrm{C}}$. The samples were taken to the laboratory for analyses using atomic absorption spectrometer (AAS). The results obtained from the laboratory were subjected to statistical analysis using SPSS. Analysis of variance (ANOVA) was employed for between and within group comparison while student's test was used for paired comparison. The T-tests associated with all the elements (silicon, aluminum, iron, calcium, zinc, lead, potassium, strontium, bromine, europium, hafnium, bismuth, niobium, and manganese) present and $\mathrm{pH}$ were found to be significant at $p<0.05$. Questionnaire which serves as the quantitative method was also prepared. The prepared questionnaire was administered to 30 quarry workers and 50 non- quarry workers. The results obtained from the questionnaires showed that quarry workers are more exposed to the effects of dust than the non-quarry workers due to the proximity. About $80 \%$ of the quarry workers have the symptom of silicosis and pneumoconiosis caused by inhalation of dust particle and those having the same symptom are less than $50 \%$ and no chronic condition was recorded.
\end{abstract}

Key Words: Point source, quantitative method, AAS, SPSS, ANOVA, student's test, questionnaire

\section{Introduction}

Dust is often used in a generic sense to describe particles which are capable of becoming airborne to disperse in the atmosphere prior to returning to surface. However, dust is considered to be any solid matter emanating from a surface mineral working, or from vehicles serving it, which is borne by the air (BSI, 1994). Dust is particle of matter in the size range of $1-75 \mu \mathrm{m}$ diameters, with particles less than $1 \mu \mathrm{m}$ being classified as smoke or fumes (BSI, 1994). Dust particles will eventually settle out under their own weight, but may remain suspended for some time. The finest particles between 1 and $10 \mu \mathrm{m}$ in diameter will be respirable and are associated with health effects. Therefore, particle less than $10 \mu \mathrm{m}$ can cause concern with health effects; particles greater than $10 \mu \mathrm{m}$ are associated with public perception and nuisance. Nuisance dust may be described as the coarse fraction of airborne particulates, typically greater than about

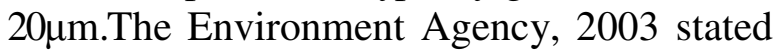
that particles greater than $30-50 \mu \mathrm{m}$ tend to be deposited quickly and as such this particle size approximates to annoyance, or nuisance dust. Such settled particles may show up as a deposit on clean surfaces such as cars and window ledges. 
Dust has different origins in a quarry site such as mechanical handling operations that include crushing and grinding process; haulage with which is related to the vehicle, and the nature and condition of the way; blasting; additional manufacturing operations and wind blow from paved areas, stockpiles etc. Dust concentration levels are monitored in two ways, active monitoring in which the system is suited to measuring over minutes, hours and days; and passive monitoring which are suited for measuring over days, weeks and months. Some ways for mitigation of dust emission are to consider the planning conditions relating to the layout of the site, design of stockpiles, hard surfacing of vehicle areas, containment of conveyors and processing plant and dust collection equipment, use of moistening equipment's on the dusty places, design of material-handling systems, provision of monitoring facilities, and measurement of limiting levels of dust.

Dust generated from granite quarry and crushing plant for construction and related industries has caused environmental problem at Gbose quarry and the near-by area. The dust problem has been so serious for the mine workers and the people living in the area. Attempts in the past has been tried to solve the problem, however it is still not so successful .The problem is increasing more serious in the past few years as the demand for the construction materials of the country is increasing. Very few quarries in the area have installed dust suppression equipment. Since 1999, the Department of Mineral Resources (DMR) of Nigeria has put strict measure to force the owner of quarries to install dust suppression equipment with the aim to reduce the dust pollution in the area to acceptable level.
Increased local and global attention being given to control of air pollution contaminant of nuisance dust in all industrial application is becoming increasingly important. This call for proper control of dusts generated, design installation, operation and maintenance of dust collection equipment. Since its inception, the fabric style dust collector (bag house) has offered companies the ability to effectively capture airborne particulate from an air stream whether toxic or not, it is necessary to provide a healthy and clean work environment (Sly, 2009). This paper therefore analysis the effect of dust generated from the point source in relation to the point of generation in Gbose Quarry.

\section{Geology of the Study Area}

Gbose quarry is located at $3 \mathrm{~km}$ to Omuaran along Oko Express Road Kwara State, Nigeria. It lies within latitude $889.509 \mathrm{~N}$ and $889.2639 \mathrm{~N}$ and longitude 58 8.31149E and 58 8.30689E. The area falls within the southern limits of the tropical Savannah one of Nigeria with mean annual rainfall of $1200 \mathrm{~mm}$ concentrated between the months of April and October and mean annual temperature varying between $31.5^{\circ} \mathrm{C}$ and $35^{\circ} \mathrm{C}$. More than $90 \%$ of the state is underlain by the basement complex rock of the Precambrian and Cambrian ages while the remaining part is underlain by cretaceous and younger sediments (Rahaman, 1976; Oyegun, 1983) undifferentiated metasediments are found in numerous large patches of the state like Lafiagi, Oke-Ode. Oke Onigbin, Omu-Aran while the older granites arc also found in numerous patches in parts of Moro. Asa and Ifelodun Local Government Areas. Quartzites are found in North Western part of Ilorin (Oyegun, 1983). Figure 1 shows the map of the study area. 


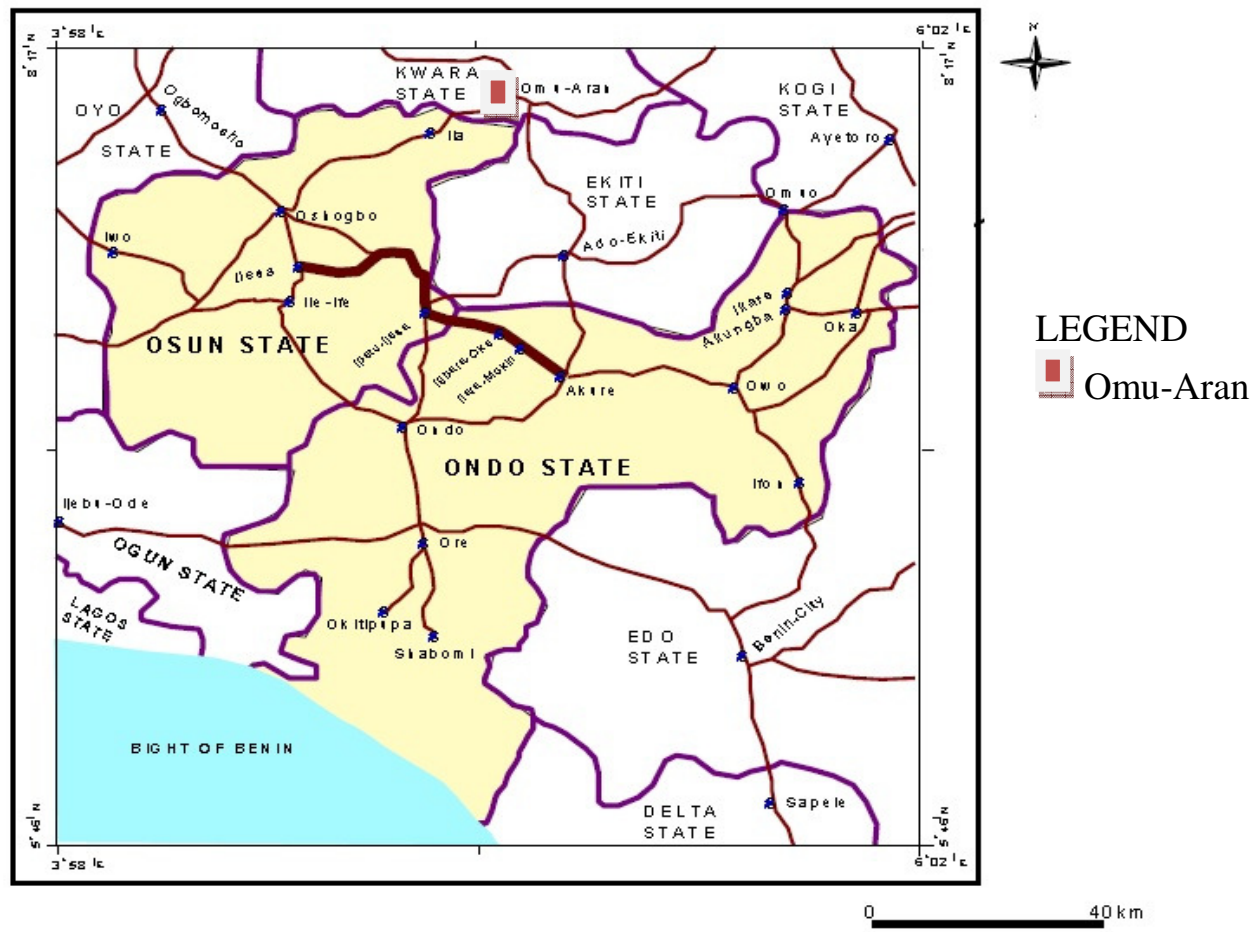

Figure 1: Map of the Study Area (adopted from Akintorinwa et al., 2010)

\section{Sample Collection and Preparation}

Dust samples were collected at the two major emission source, which are fugitive source (not collectable) and the processed source (final product) within the crushing plant using manual system. In the manual system, the crushing area was marked with poles about $20 \mathrm{~m}$ tall with polythene attached at the top at six points at $50 \mathrm{~m}$ intervals. One control sample was also taken at $300.0 \mathrm{~m}$ away from the quarry site. The samples were collected into appropriately labelled containers, preserved and stored. Samples $\mathrm{SS}_{1}, \mathrm{SS}_{2}, \mathrm{SS}_{3}, \mathrm{SS}_{4}, \mathrm{SS}_{5}$ and $\mathrm{SS}_{6}$ indicate dust samples taken from the quarry area while $\mathrm{SS}_{\mathrm{C}}$ indicates sample taken from control station. The adopted preparation method followed the standard suggested by Asia Life Science Service Resource Guide.

\section{Test Equipment and Materials}

The equipment and materials used are: freeze dryer, specimen cup, minipal 4 spectrometer, and Pentium M Computer.

\section{Procedure}

Some portion of samples from the study areas were taken and dried in a freeze drier. $1 \mathrm{~g}$ of each of the samples were weighed and put in a specimen cup (Plate 3.1 shows a typical specimen cup). The specimen cups were loaded into a minipal 4 spectrometer. The spectrometer was put on and it accelerated centrifugally for several minutes until it stops automatically. The elements present in the dust particle sample were displayed on the screen of attached computer and the results were printed.

\section{Determination of $p H$ of the Dust Particle}

The $\mathrm{pH}$ measurement involved inserting the probe of the $\mathrm{pH}$ meter into a 1:1 ratio suspension of the sample in distilled water. The $\mathrm{pH}$ of each sample was determined with a $\mathrm{pH}$ meter in accordance with ASTM D4972. Prior to sample analysis, the meter was calibrated according to manufacturer instruction with buffer solutions 4, 7 and 10 . $10 \mathrm{~g}$ of dust sample was weighed into $100 \mathrm{ml}$ baker. $20 \mathrm{ml}$ of distilled water was added to 
each. The suspension was stirred several times over a 30 minute interval with a glass rod. The $\mathrm{pH}$ of the dust in each beaker was measured and recorded. The same procedures were followed for the remaining samples.

\section{Data Analyses}

Chemical composition of dust samples were analyzed statistically using a Statistical Package for Social Sciences (SPSS) software. The analyses of all the samples at each distance from the source were carried out in quadriplicates. The statistical values were reported as mean 6 standard error of the mean (SEM) and analysis of variance (ANOVA) was also used for group comparison for between and within group while student's test was used for paired comparison. The $p$-value of $p<0.05$ is statistically considered significant.

\section{Field Data}

Questionnaires were administered to 30 quarry workers and a control population of 50 non-quarry workers (smokers and those who responded affirmatively to the question). Demographic data of respondents were collected to ascertain the occurrence of respiratory symptoms.

\section{Results and Discussion}

Tables $1 \mathrm{a}$ and $1 \mathrm{~b}$ shows the percentage chemical composition of dust sample using statistical package for social sciences software (SPSS). Tables 2 to 5 show the result from the analyses of the retrieved questionnaires.

The mean values of the chemical elements present in the dust samples obtained at $0.00 \mathrm{~m}, 50 \mathrm{~m}, 100 \mathrm{~m}, 150 \mathrm{~m}, 200 \mathrm{~m}, 250$ $\mathrm{m}$ and $300 \mathrm{~m}$ from the sources as obtained from the SPSS software are presented in Tables 4.1a and $4.1 \mathrm{~b}$ respectively. From Table 4.1a the mean value of $\mathrm{pH}$ ranges from 3.5260 .004 to 8.5060 .004 . The $\mathrm{pH}$ of dust sample at $0 \mathrm{~m}$ distance is 4.4060 .071 which is highly acidic, at $200 \mathrm{~m}$ distance from the source of generation the $\mathrm{pH}$ is of low acidic and at $300 \mathrm{~m}$ distance from the source the $\mathrm{pH}$ value is high alkalinity. The mean values of Aluminum range between 6.6760 .004 and 14.7660 .051 respectively while that of silicon varies between $13.83 \quad 60.007$ and 22.8060 .007 respectively as show in Table 4.1a. According to Lenntech, (1998) silicon has little adverse effect on lungs and does not appear to produce significant organic disease when exposure is kept below the exposure limit. The mean values of potassium obtained from the analysis ranges between 0.004 60.041 and 0.7060 .004 . The mean values of calcium present varies from 2.9360 .025 to 4.0060 .041 respectively. The distribution of calcium is wide and this element is essential for life of plant and animal for growth and low concentration of calcium is one of the main causes of osteoporosis (Lenntech, 1998). The mean values of iron oxide varies from $7.648 \quad 60.005$ to $18.806 \quad 0.041$ respectively. Chronic inhalation of excessive concentration of iron oxide fumes or dust may result in development of benign pneumoconiosis called siderosis which is observable as an x-ray change. The mean values of bromine vary between $0.040 \pm$ 0.041 and $0.20 \pm 0.011$ respectively while that of Strontium vary from 2.8060 .011 to 1.3260 .040 as shown in Table 4.1a respectively. Strontium in its elemental form occur relatively in many compartment of the environment including rocks dust particle that contain strontium will settle to surface water soil or plant at source point (Lenntech, 1998). The mean values of the lead concentration in the samples range from 3.6760 .007 to 0.03060 .0041 while the mean concentration of europium varies between 0.03060 .0041 and $2.20 \pm 0.015$ as shown in Table 1b. The concentration of Hafium varies between $1.54 \pm 0.0041$ and $7.40 \pm 0.091$ and that of bismuth varies between $0.003 \pm 0.000$ and $0.013 \pm 0.004$ respectively as shown in Table 1b. The mean concentration of niobium varies between $0.0975 \pm 0.009$ and $0.020 \pm$ 356 
0.004 and that of zinc ranges between $0.005 \pm 0.001$ and $0.0008 \pm 0.000$ as shown in Table $4.1 \mathrm{~b}$ respectively. The mean concentration of manganese varies between $0.30 \pm 0.004$ and $0.008 \pm 0.000$ respectively. Tables 4.2 to 4.4 show the results obtained from the accomplished questionnaires. From the results the main ailment that affects the people in and around the quarry is asthma, headache and shock as a result of the noises generated from the quarry.

\section{Conclusion}

This study reveals that occupational exposure to dust is still a major cause of concern in quarries in Nigeria where quarrying is a means of earning a living, especially for people in Omu Aran. This study at Gbose quarry is just the tip of the iceberg and is indicative of what is obtainable in other quarry Companies in Nigeria. The chemical analysis of the dust generated from the study area was carried out and questionnaires were also accomplished to both the workers and people living around the quarry. From the results of the analysis and accomplished questionnaires the following conclusions were reached: All the elements that are present in the dust samples and their $\mathrm{pH}$ are significant at 5\% significant level. Silicosis is the main disease affecting the quarry workers and cough, catarrh and shock are the main effects caused by the quarry activities to the people leaving around the quarry site.

\section{References}

Akintorinwa, O.J., Ojo, J.S. and Olorunfemi, M.O. (2010). "Geophysical Investigation of Pavement Failure in a Basement Complex Terrain of Southwestern Nigeria". Pacific Journal of Science and Technology. 11(2):649-663.

British Standards Institution (BSI) (1969). "Method for the Measurement Air Pollution Deposit Gauge BSI747-1: BSI London, p. 20.
British Standards Institution (BSI) (1972). Method for the Measurement of Air Pollution. Directional Dust Gauge, BSI747-5: 1972, BSI London, p. 82

Environmental Agency (2003). Monitory Particulate Matter in Ambient Air around Waste facilities: Technical Guidance Document (monitory) M17. Environmental Agency, London. p. 98

Environmental Protection Agency (2000). Environmental Monitory Strategy-Ambient Air: Technical Guidance Note M8" Environmental Agency London, p. 75

Environmental Protection Agency (2004). Ghana Environmental Protection Agency State of the environment Report, SOE, p. 85

EPA (2007). Technical Transfer Network Cleaning House for Inventories and Emission Factors: AP-42 Emission Factors. US Environmental Protection Agency, p. 40

Nnorom, I.C. and Osibanjo, O. (2002). "Determination of Lead and Cadmium Content of Dry Cell Batteries Available in Nigeria" J. Appl Sci Environ Manag., 10: 37-41.

Olsson, I.M., Ericksson, J., Oborn, I., Skerfving, S. and Oskarsson, A. (2005). "Cadmium in Food Production Systems" Health Risk for Sensitive Populations. Ambio., 34: 344-51.

Onianwa, P.C. and Fakayode, S.O. (2000). "Lead Accumulation of Top Soil and Vegetation in the Vicinity of a Battery Factory in Nigeria". Environ Geochem Health, 22: 211-18.

Rahman, M.A. (1976). Review of the Basement Geology of South Western Nigeria. In Geology of Nigerian, Edited by C.A Kogbe, Elizabethan Publishing Company, Lagos, Nigeria, pp. 41-58.

Smith, D.R. and Flegal, A.R. (1995). "Lead in the Biosphere, Recent Trends". Ambio; 24: 21-3.

World Health Organization (1999). "Prevention and Control Exchange: Hazard Prevention and Control in the Work Environment. Geneva: WHO; p. 219. 
Table 1a: Chemical Analysis Result of a Dust Samples using (SPSS)

\begin{tabular}{lcccccccc}
\hline$* \mathrm{DQ}$ & $\mathrm{pH}$ & $\mathrm{Al}$ & $\mathrm{Si}$ & $\mathrm{K}$ & $\mathrm{Ca}$ & $\mathrm{Fe}$ & $\mathrm{Br}$ & $\mathrm{Sr}$ \\
\hline 0.00 & $4.40 \pm 0.071$ & $14.76 \pm 0.051$ & $22.80 \pm 0.007$ & $0.70 \pm 0.004$ & $4.00 \pm 0.041$ & $18.80 \pm 0.041$ & $0.20 \pm 0.011$ & $2.80 \pm 0.011$ \\
50.00 & $4.90 \pm 0.004$ & $13.64 \pm 0.009$ & $20.73 \pm 0.0041$ & $0.70 \pm 0.0204$ & $3.70 \pm 0.041$ & $17.40 \pm 0.041$ & $0.20 \pm 0.007$ & $2.65 \pm 0.007$ \\
100.00 & $4.96 \pm 0.009$ & $12.50 \pm 0.037$ & $19.81 \pm 0.0041$ & $0.653 \pm 0.005$ & $3.550 \pm 0.004$ & $16.90 \pm 0.007$ & $0.180 \pm 0.004$ & $2.550 \pm 0.004$ \\
150.00 & $3.52 \pm 0.004$ & $10.38 \pm 0.004$ & $17.985 \pm 0.00645$ & $0.0048 \pm 0.005$ & $0.0041 \pm 0.0041$ & $15.45 \pm 0.065$ & $0.170 \pm 0.004$ & $2.47 \pm 0.004$ \\
200.00 & $6.788 \pm 0.005$ & $9.453 \pm 0.006$ & $16.848 \pm 0.125$ & $0.618 \pm 0.005$ & $3.48 \pm 0.0041$ & $14.90 \pm 0.041$ & $0.153 \pm 0.005$ & $2.408 \pm 0.005$ \\
250.00 & $7.891 \pm 0.004$ & $7.54 \pm 0.004$ & $14.80 \pm 0.0071$ & $0.590 \pm 0.004$ & $3.07 \pm 0.0041$ & $10.80 \pm 0.041$ & $0.090 \pm 0.004$ & $2.35 \pm 0.004$ \\
300.00 & $8.50 \pm 0.004$ & $6.67 \pm 0.004$ & $13.83 \pm 0.0071$ & $0.400 \pm 0.041$ & $2.93 \pm 0.02$ & $7.648 \pm 0.005$ & $0.040 \pm 0.041$ & $1.32 \pm 0.040$ \\
\hline
\end{tabular}

$* \mathrm{D}_{\mathrm{Q}}$ means distance from the source

Table 1b: Chemical Analysis Result of a Dust Samples using (SPSS)

\begin{tabular}{lccccccc}
\hline$* \mathrm{DQ}$ & $\mathrm{Pb}$ & $\mathrm{Eu}$ & $\mathrm{Hf}$ & $\mathrm{Bi}$ & $\mathrm{Nb}$ & $\mathrm{Zn}$ & $\mathrm{Mn}$ \\
\hline 0.00 & $9.40 \pm 0.108$ & $2.20 \pm 0.015$ & $7.40 \pm 0.091$ & $0.013 \pm 0.004$ & $0.0975 \pm 0.009$ & $0.005 \pm 0.001$ & $0.30 \pm 0.004$ \\
50.00 & $8.40 \pm 0.041$ & $2.10 \pm 0.007$ & $6.0 \pm 0.071$ & $0.012 \pm 0.000$ & $0.090 \pm 0.004$ & $0.004 \pm 0.000$ & $0.300 \pm 0.008$ \\
107.00 & $7.95 \pm 0.004$ & $1.80 \pm 0.007$ & $5.52 \pm 0.004$ & $0.011 \pm 0.000$ & $0.080 \pm 0.004$ & $0.0035 \pm 0.000$ & $0.250 \pm 0.000$ \\
150.00 & $7.45 \pm 0.004$ & $1.65 \pm 0.004$ & $5.08 \pm 0.004$ & $0.009 \pm 0.000$ & $0.068 \pm 0.005$ & $0.003 \pm 0.000$ & $0.245 \pm 0.004$ \\
200.00 & $6.45 \pm 0.004$ & $1.53 \pm 0.804$ & $4.82 \pm 0.004$ & $0.008 \pm 0.000$ & $0.058 \pm 0.005$ & $0.0025 \pm 0.000$ & $0.221 \pm 0.0005$ \\
250.00 & $5.45 \pm 0.007$ & $1.100 \pm 0.004$ & $3.67 \pm 0.007$ & $0.006 \pm 0.000$ & $0.050 \pm 0.004$ & $0.002 \pm 0.000$ & $0.199 \pm 0.000$ \\
300.00 & $3.67 \pm 0.007$ & $0.030 \pm 0.004$ & $1.54 \pm 0.004$ & $0.003 \pm 0.00$ & $0.020 \pm 0.004$ & $0.0008 \pm 0.000$ & $0.008 \pm 0.000$ \\
\hline
\end{tabular}

$* \mathrm{D}_{\mathrm{Q}}$ means distance from the source 
Table 2: Showing Sex, Residency Duration, and Distance to Quarry, Observed Impacts and Health Problems Experienced by People Living near Quarry Site

\begin{tabular}{ccc}
\hline Sex & No. of respondent & Percentage $\%$ \\
\hline Male & 37 & 74 \\
Female & 13 & 26 \\
Total & 50 & 100 \\
Residency duration & 13 & 26 \\
1-5 years & 10 & 20 \\
6-10 years & 11 & 22 \\
11-15 years & 9 & 18 \\
16-20 years & 7 & 24 \\
>20 years & 50 & 100 \\
Total & & \\
Distance to Quarry site & 8 & 16 \\
<100 m & 3 & 6 \\
100-250 m & 9 & 18 \\
251-500 m & 30 & 60 \\
500-1000 m & 50 & 100 \\
Total & & \\
Quarrying Impact & 10 & 20 \\
Noise and ground & & \\
Vibration & 7 & 14 \\
Noise alone & 13 & 26 \\
Air pollution by dust & 19 & 38 \\
Ground vibration alone & 1 & 2 \\
No felt problem & 50 & 100 \\
Total & 18 & 36 \\
Health problems & 20 & 40 \\
catarrh & 50 & \\
Shock & & \\
Cough & & \\
Total & & \\
& & \\
\hline & & \\
\hline
\end{tabular}

Table 3: Showing Age- Group and Job Specification of Sampled Quarry Workers

\begin{tabular}{lll}
\hline Age-group & No. of respondents & Percentage \\
\hline 20-35 years & 9 & 30 \\
36- 50 years & 15 & 50 \\
>50 years & 6 & 20 \\
Total & 30 & 100 \\
Job specification & & \\
Drillers & 3 & 10 \\
Blasters & 6 & 20 \\
Maintenance worker & 4 & 13 \\
Administrative worker & 5 & 17 \\
Crusher mechanics & 7 & 23 \\
Crusher operators & 5 & 17 \\
Total & 30 & 100 \\
\hline
\end{tabular}


Table 4: Relationship between Quarrying and Occurrence of Respiratory Disease Symptoms and Dermatoses

\begin{tabular}{lcccc}
\hline Characteristic & Yes & No & $\begin{array}{l}\text { Percentage } \\
\text { Yes }\end{array}$ & $\begin{array}{l}\text { Percentage } \\
\text { No }\end{array}$ \\
\hline Knowledge of effect on health & 6 & 24 & 20 & 80 \\
Wearing of overalls & 8 & 22 & 27 & 73 \\
Covering of nostrils & 14 & 16 & 46 & 54 \\
Eye goggles & 0 & 30 & 0 & 100 \\
\hline
\end{tabular}

Table 5: Health Problems Diagnosed among Quarry Workers

\begin{tabular}{lllllll}
\hline Health problem & Very High & High & Average & Low & Very Low & $\begin{array}{l}\text { Percentage (average) } \\
\%\end{array}$ \\
\hline Cough & 5 & 3 & 10 & 2 & 3 & 33 \\
Acute malaria & 0 & 0 & 0 & 10 & 19 & 0 \\
Dermatitis (skin infection) & 0 & 0 & 4 & 7 & 10 & 13 \\
Hypertension & 0 & 0 & 3 & 17 & 10 & 10 \\
Nausea (vomiting) & 0 & 0 & 6 & 7 & 10 & 20 \\
Catarrh & 3 & 2 & 8 & 0 & 13 & 27 \\
Chest pain & 0 & 5 & 10 & 6 & 4 & 33 \\
Asthma & 0 & 2 & 17 & 6 & 5 & 57 \\
Headaches & 1 & 9 & 14 & 3 & 3 & 47 \\
Silicosis (lung disease) & 0 & 3 & 18 & 3 & 3 & 60 \\
\hline
\end{tabular}

